Jpn. J. Vet. Sci. 45(1), 91-96 (1983)

\title{
X-Ray Microanalysis of Intact and Regenerated Vessel Wall of the Canine Abdominal Aorta
}

\author{
Takashi MAKITA, Masanori HATSLOKA, Kazushige OGAWA, \\ Sukechika KIWAKI, and Koji SASAKI ${ }^{1}$ \\ Department of Veterinary Anatomy, Yamaguchi Lnzersity, 1677-1 Yoshida, Yamaguchi, \\ Yamaguchi 753, and 'Department of Veterinary Hygiene, Azabu L'mzersity, \\ 1-17-71 Fuchmobe, Sagamihara, Kanagaw'a 229
}

(Received 28 May 1982/Accepted 30 November 1982)

\begin{abstract}
Physiologically important elements ( $\mathrm{Fe}, \mathrm{Ca}, \mathrm{Mg}, \mathrm{Cl}, \mathrm{K}, \mathrm{S}$ and $\mathrm{P}$ ) were surveyed with a wave length dispersive X-ray microanalyser (WDX) attached to SEM on cross section of freeze-dried bulk specimens of canine abdominal aorta after denudation of the endothelial cells with a balloon catheter. Fe was unexpectedly the major element at every spot examined while $\mathrm{P}$, $\mathrm{Ca}$ and $\mathrm{K}$ were only moderate in amounts. Traces of $\mathrm{Mg}, \mathrm{Cl}$ and $\mathrm{S}$ were found in the smooth muscle, erythrocytes, platelets and endothelial cells. There was little difference in the levels of the above mentioned elements between intact and regenerated endothelial cells.
\end{abstract}

The response of the endothelial cells and the intimal smooth muscle cells in the abdominal aorta of such experimental animals as the monkey, swine, rabbit, hamster, rat and chicken after ballooning with a catheter has been investigated in several laboratories including ours [3, $4,6,10-14,20,21,23]$ by both scanning (SEM) and transmission (TEM) electron microscopy. There are a variety of approaches to this subject, such as staining with Evans blue [22], peroxidase and ruthenium red. X-ray microanalysis of elements in the regenerated endothelial cells, however, has not previously been reported to the best of our knowledge.

This report is an extension of the work on the project of quantitative analysis of recovery of the endothelium of the canine aorta after denudation by ballooning and an attempt to detect major elements by a wave length dispersive $\mathrm{X}$-ray detector (WDX) in the secondary electron image (SEM picture) of bulk specimens.

\section{Materials ANd Methods}

A total of eight male beagle dogs were used for this SEM study. Six of them were analyzed with a WDX-SEM system. Two dogs were used for SEM study only. The control dogs were not ballooned. The rest of the dogs were ballooned with a Fogaty arterial embolectomy catheter (Edwards Lab., Model 12-080-5F, size 5, AHS-Japan) and sacrificed in either 30 min. or 4 weeks after ballooning. The ballooned dogs were first sedated with ketamine $\mathrm{HCl}(10 \mathrm{mg} / \mathrm{kg})$, then anesthetized with sodium pentobarbital before exposing the left femoral artery to insert the catheter. The balloon was pulled back and forth 10 times. The dogs were sacrificed with an electric current (100v) and the abdominal aorta distal to the celiac artery was dissected out and fixed in cold glutaraldehyde (4\%) buffered with $0.1 \mathrm{M}$ sodium cacodylate- $\mathrm{HCl}$ at $\mathrm{pH}$ 7.4 for 6 to $7 \mathrm{hr}$ at $4^{\circ} \mathrm{C}$. Tissue blocks sliced with a razor blade were washed by 
several changes of the cold buffer and freeze-dried (an Edwards-Pearse tissue drier EPD 2) for 3 days under vacuum $\left(10^{-3}\right.$ torr $)$ at $-35^{\circ} \mathrm{C}$. The dried specimens were coated with evaporated carbon and/or gold for observation and analysis in the WDX-SEM system. Survey for $\mathrm{Fe}, \mathrm{Ca}, \mathrm{Mg}, \mathrm{Cl}, \mathrm{K}, \mathrm{S}$ and $\mathrm{P}$ were conducted with TAP and PET crystals of WDX. The operating conditions of the instrument were: specimen absorbing current, 1.5 to $2.0 \times 10^{-8} \mathrm{~A}$; duration of analysis on one spot, $10 \mathrm{sec}$; accerating voltage, $15 \mathrm{kv}$; diameter of electron probe approximately $0.2 \mu \mathrm{m}$. Results were obtained from 7 to 12 points on each target structure in terms of mean count/10 sec + S.D. The background, the average of pre- and post-peak readings, was substracted from the peak value.

\section{Results}

Secondary electron image (SEM) of the ballooned canine abdominal aorta in cross section shows numerous erythrocytes attached to the luminal surface and layers of smooth muscles of intima and media (Figs. 1 and 2). Four weeks after ballooning, most of the luminal surface was covered with regenerating lining cells (Fig. 3). Dark and light types of endothelial cells $[14,20]$ are hardly distinguishable by SEM. As would be ex- pected, platelets, macrophages and lymphocytes as well as red and white blood cells are widely distributed over the regenerated endothelial surface. Fig. 4 shows a platelet on which several point analyses were made to obtain the results shown in Table 1. The points were analyzed on the cut surface of smooth muscle layers (Fig. 2), several erythrocytes (Fig. 2) and regenerated endothelial cells (Fig. 3). Spot analyses of the intact endothelial cells are also included in Table 1. Unexpectedly high counts of $\mathrm{Fe}$ were found in every substructure surveyed. The levels of $\mathrm{P}, \mathrm{Ca}$, and $\mathrm{K}$ were moderate and much lower than predicted, indicating a loss of such elements in the course of specimen preparation. These elements were not detected with the energy dispersive $\mathrm{X}$ ray microanalyzer (EDX) either. $\mathrm{Mg}, \mathrm{Cl}$, and $\mathrm{S}$ were minor elements and present in trace amouts only.

There was little difference between intact and regenerating endothelial cells in the amounts of the above-mentioned elements. None of these elements served as an indicator of the recovery of the endothelial cells. A possible difference in ultrastructural localization of elements is not detectable by this method. The extremities of platelets appeared to contain slightly greater concentrations of these elements, except $\mathrm{K}$, than the cell body.

Table 1. WDX survey of elements on freeze-dried canine abdominal aorta of intact and regenerated after denudation of the endothelium with a catheter

\begin{tabular}{lcrrrrrr}
\hline \multirow{2}{*}{ Element } & Smooth m. & Erythrocyte & \multicolumn{2}{c}{ Platelet } & Intact & $\begin{array}{c}\text { Regenerated } \\
\text { endothelium }\end{array}$ \\
\cline { 5 - 7 } & & & cell body & projections & endothelium & & \\
\hline Fe & $2137 \pm 441^{*}$ & $3893 \pm 409$ & $2155 \pm 409$ & $2741 \pm 456$ & $1988 \pm 235$ & $2718 \pm 353$ \\
P & $405 \pm 66$ & $644 \pm 151$ & $448 \pm 82$ & $593 \pm 68$ & $618 \pm 44$ & $557 \pm 65$ \\
Ca & $222 \pm 61$ & $87 \pm 25$ & $135 \pm 19$ & $183 \pm 45$ & $210 \pm 36$ & $178 \pm 10$ \\
K & $165 \pm 28$ & $159 \pm 16$ & $221 \pm 15$ & $176 \pm 32$ & $248 \pm 39$ & $200 \pm 16$ \\
Mg & $39 \pm 12$ & $29 \pm 17$ & $46 \pm 18$ & $57 \pm 12$ & $39 \pm 14$ & $45 \pm 15$ \\
Cl & $56 \pm 3$ & $79 \pm 17$ & $18 \pm 6$ & $24 \pm 9$ & $36 \pm 11$ & $42 \pm 8$ \\
S & $37 \pm 3$ & $39 \pm 10$ & $27 \pm 6$ & $31 \pm 9$ & $11 \pm 3$ & $16 \pm 5$ \\
\hline
\end{tabular}

* mean count of 7 to 12 spots $/ 10 \mathrm{sec} \pm$ S.D 
This might reflect the condensation of the elements during the drying procedure.

The detection of Fe in smooth muscle, platelets and endothelial cells requires further investigation.

\section{Discussion}

The source of iron in the erythrocytes must be hemoglobin [9] but a considerably high level of iron in the smooth muscle, endothelial cells and platelets is difficult to interpret. It is known that the sensitivity of WDX to detect $\mathrm{Fe}$ is higher than that to detect $\mathrm{P}$, Ca or $\mathrm{K}$. The possibility of translocation of $\mathrm{Fe}$ from the erythrocyte to the smooth muscle and the endothelium is one of the factors to be examined. Phosphorus might be derived from membrane phospholipids or the granules of platelets and endothelial cells. The potassium contents have been reported to be $114-121 \mathrm{mM}$ in the smooth muscle [1] and $9-10 \mathrm{mEq} / \mathrm{l}$ in erythrocytes [8]. Both calcium and magnesium are reported to be involved in contraction of the smooth muscle of the vessel walls [2, 17], but magnesium was found only in a trace amount in this experiment. Sulfur may be localized in mucopolysaccharides of the vascular wall [16], but both sulfur and chlorine were in very small amounts in every spot surveyed.

On the two types of X-ray microanalyzer, WDX requires a flatter specimen surface and 10 to 100 times grater specimen current than EDX. Therefore, WDX is not recommended for biological specimens [5]. However, the sensitivity of WDX is nearly 10 times higher than that of EDX. In fact, iron, the most highly concentrated element in avian erythrocytes [9] was difficult to detect with EDX in this survey. Another technical problem was that bulk specimens of biological tissues are not suitable for X-ray microanalysis due to their uneven surface and depth and the difficulty in identification of the ultrastructure. The only reason for daring to utilize WDX for bulk specimens was that we were unable to detect elements in semi-thin $(300-500 \mathrm{~nm}$ thick) sections of routinely prepared epoxy embedded samples by EDX. Recently we detected considerable amounts of $\mathrm{P}, \mathrm{S}, \mathrm{Cl}$ and $\mathrm{K}$ in hydrated specimens of aorta of the rabbit with the EDX-WET SEM system [15]. Similar observations on artificial thrombus and the vessel wall of the canine saphena vein $[7,18,19]$ are in progress.

ACKnowledgement. This work was partly supported by a Grant-in-Aid for Scientific Research from the Ministry of Education Science and Culture of Japan. We thank Dr. G. M. Jeffree of Bristol Royal Infirmary and Dr. K. T. Lee of Albany Medical College for commenting on the manuscript. Suggestions made by Dr. T. Abe of Teikyo University to this project are highly appreciated.

\section{REFERENCES}

1. Altman, P. L., and Dittmer, D. S. (1973). Biology Data Book. 2nd ed. vol. II. Federation of American Societies for Experimental Biology. Bethesda, Maryland, 1235.

2. Altura, B., and Altura, B. T. (1981). Magnesium ions and contraction of vascular smooth muscle: relationship to some vascular diseases. Fed. Proc. 40, 2672-2679.

3. Chicli, C. C., and Insull, W. (1977). Rate of regrowth of arterial endothelium in vivo after injury. Surgery Forum. 28, 219-221.

4. Friedman, R. J., Stemerman, M. B., Wenz, B., Moore, S., Gauldie, J., Gent, M., Tiell, M. L., and Spaet, T. H. (1977). The effect of thrombocytopenia on experimental arteriosclerotic lesion formation in re-endothelialization. J. Clin. Invest. 60, 1191-1201.

5. Goodhew, P. J. (1975). Analytical information from an electron microscope. In "Electron Microscopy and Analysis" by Goodhew, P. J. Wykeham Publications, London, 117185.

6. Haudenschild, C. C., and Schwarz, S. M. (1979). Endothelial regeneration. II. Restitution of endothelial continuity. Lab. Invest. 
41, 407- 418 .

7. Hatsuoka, M., and Makita, T. (1981). Scanning electron microscopy of experimental thrombus formation in canine lateral saphena vein. J. Scanning Electron Microscopy, 1981 IV; 189-194.

8. Kaneko, J. J. (1980). Chapter 4. In "Clinical Biochemistry of Domestic Animals" 3 rd ed. by Kaneko, J. J. Academic Press, New York and London, 134.

9. Makita, T. (1973). Detection of $\mathrm{Fe}$ in the nucleus of mature erythrocytes of the pigeon. The Hitachi Scientific Instrument News. 16, $12-14$.

10. Makita, T., and Lee, K. T. (1979). Fine structure of elastic layer and other features of intimal smooth muscle cell mass in the abdominal aorta of swine. Proc. Intern. Symp. Atherosclerosis (Houston, Texas), 32.

11. Makita, T. (1980). Secretion of basal membrane substance from endothelial cells of swine abdominal aorta. Proc. 36th Japan Electron Microscope Society, 274.

12. Makita, T., Ogawa, K., and Watanabe, J. (1981). Junctional complex in regenerating abdominal aorta. Proc. 37th Japan Anatomists Assn., 115.

13. Makita, T., Watanabe, J., Ogawa, K., and Kiwaki, S. (1981). Regeneration of endothelial cells of canine abdominal aorta. Proc. 86th Japan Anatomists Assn., 215.

14. Makita, T., and Ogawa, K. (1981). Reendothelialization in abdominal aorta of canine after denudation by balloon catheter. Anat. Rec. 199, 157A.

15. Makita, T., Ueda, H., Hirose, H., and Idego- mori, T. (1982). X-ray microanalysis of hydrated biological specimens. Scanning Electron Microscopy/1982 III: 1215-1210.

16. Murata, K. (1975). Acidicglycosoaminoglycans in vascular walls. Metabolism and Disease (in Japanese) 12, 1299-1310.

17. Nonomura, Y. (1975). Contractile proteins of smooth muscle. Metabolism and Disease (in Japanese) 12, 1767-1784.

18. Sasaki, K., Hatsuoka, M., Toki, N., Sumi, H., and Makita, T. (1980). Fibrinolytic and coagulation activity level during formation of experimental thrombus in dog's saphena vein. Life Sciences 27, 1659-1665.

19. Sasaki, K., Hatsuoka, M., and Makita, T. (1981). Scanning electron microscopy of artificial thrombus in canine saphena vein. Proc. 37 th Japan Electron Microscope Society, 117.

20. Schwartz, S. M., Stemerman, M. B., and Benditt, E. P. (1975). The aortic intima. II. Repair of the aortic lining after mechanical denudation. Amer. J. Pathol. 81, 15-42.

21. Scott, R. F., Imai, H., Makita, T., Thomas, W. A., and Reiner, J. M. (1980). Lining cell and intimal smooth muscle cell response and Evans blue staining in abdominal aorta of young swine after denudation by balloon catheter. Exptl. Molec. Pathol. 33, 185-202.

22. Scott, F., Lee, W. M., Lee, K. T., and Kim, N. N. (1980). Evans blue dye. Arch. Pathol. Lab. Med. 104, 625-630.

23. Spaet, T. H., Stemerman, M. B., Veith, F. J., and Lenieks, I. (1975). Intimal injury and regrowth in smooth muscle cells as a source of neointima. Circulation Research 36, 58-70.

\section{Explanation of Figures}

Fig. 1. A scanning electron micrograph of a cross section of the abdominal aorta of a beagle dog 30 minutes after catheter ballooning. Coated with gold. $15 \mathrm{kv} . \times 200$.

SM-I: Smooth muscle of intima, SM-M: Smooth muscle of media.

Fig. 2. A higher magnification of the vessel wall and thrombus attaching to it. 30 minutes after catheter ballooning. Coated with gold. $15 \mathrm{kv} . \times$
2000.

Fig. 3. A lumenal surface view of regnerated endothelial cells 4 weeks after catheter ballooning. Canine abdominal aorta near celiac artery. $15 \mathrm{kv} . \times 2000$.

Fig. 4. A high power view of a part of Fig. 3 to illustarate a platelet with many cytoplasmic projections. Coated with gold. $15 \mathrm{kv} . \times 10000$. 


\section{要 約}

イヌの腹大動脈の正常および再生血管壁の X 線微量分析：牧田登之・初岡政典 - 小川和重・木 脇祐順・佐々木耕治 ${ }^{1)}$ (山口大学農学部家畜解剖学教室, ${ }^{1}$ 麻布大学家畜衛生学教室) 一一ビーグル 犬の正常および動脈カテーテルで内皮を剥離後修復した腹大動脈を走查電子顕徽鏡で観察し, 試 料断面で血管の内皮細胞, 平滑筋線維, 赤血球, 血小板に含まれる $\mathrm{Fe}, \mathrm{P}, \mathrm{Ca}, \mathrm{K}, \mathrm{Mg}, \mathrm{Cl}, \mathrm{S}$ 各元素を波長分散型微量 X 線検出器 (WDX) で分析した。生鮮試料では $\mathrm{P}, \mathrm{S}, \mathrm{Cl}, \mathrm{K}$ が主要元 素であったのに対し, 凍結乾燥試料では $\mathrm{Fe}$ が予想外に多く, $\mathrm{P}$ は中程度で, $\mathrm{Ca}$ と $\mathrm{K}$ は低く検出 され, $\mathrm{Mg}, \mathrm{Cl}, \mathrm{S}$ は微量であった. 内皮剥離後4 週の再生内皮細胞では $\mathrm{Fe}$ が正常值よりやや高 く, $\mathrm{P}, \mathrm{Ca}, \mathrm{K}$ がやや低い值を示したが， $\mathrm{Mg}, \mathrm{Cl}, \mathrm{S}$ 值は非常に低く，正常・再生内皮細胞間に 顕著な差はみられなかった。血小板では細胞体より細胞質突起で $\mathrm{Fe}, \mathrm{P}, \mathrm{Ca}$ が高値であった。走 查電子顕微鏡では再生内皮の明細胞と暗細胞の判別が困難であった。 

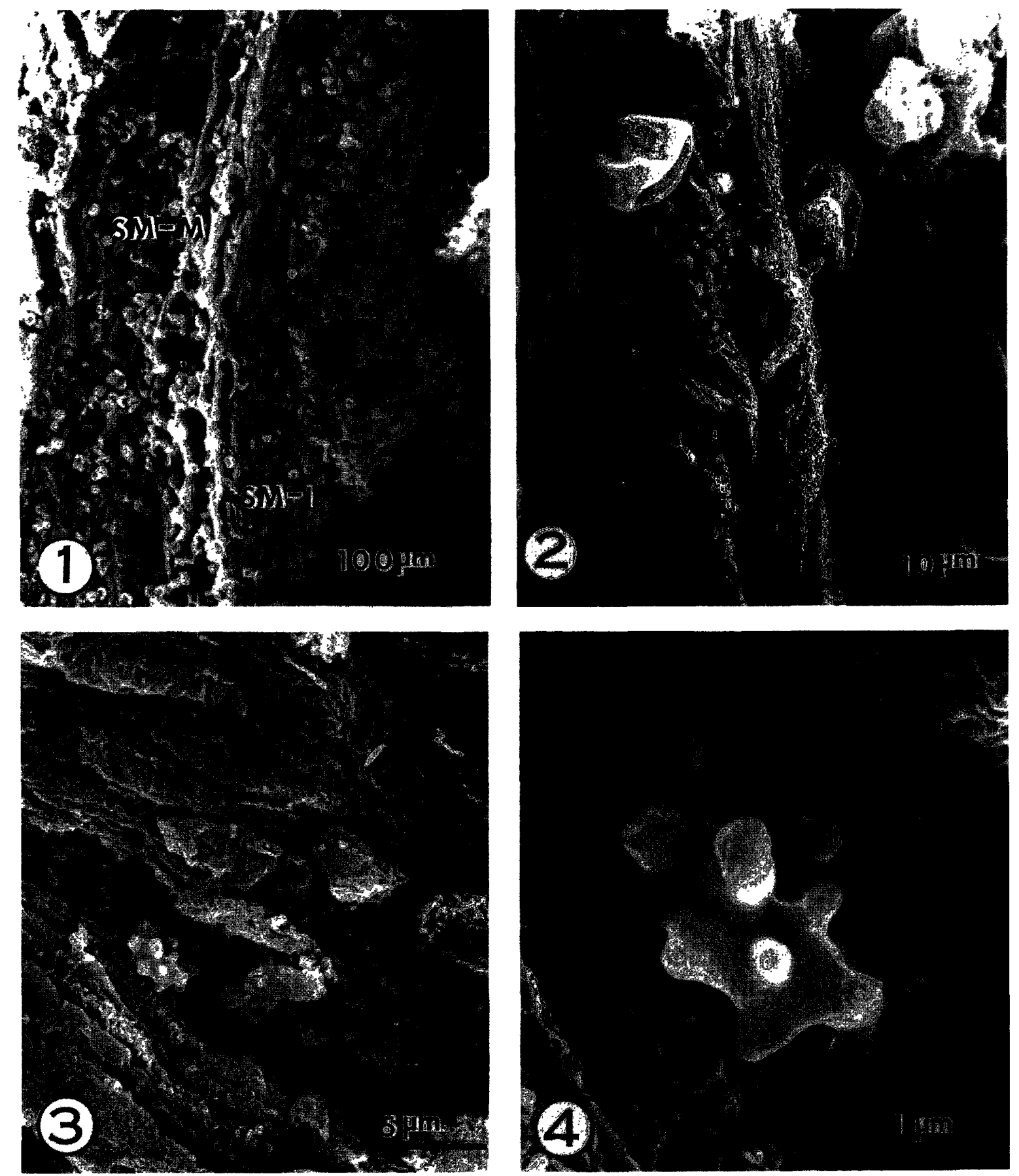